\title{
PENGARUH KONSENTRASI AGAR-AGAR DAN KARAGENAN TERHADAP KARAKTERISTIK FISIK, KIMIA, DAN SENSORI SELAI LEMBARAN JAMBU BIJI MERAH (Psidium guajava L.)
}

\section{THE INFLUENCE OF AGAR AND CARRAGEENAN CONCENTRATION ON PHYSICAL, CHEMICAL, AND SENSORY CHARACTERISTICS OF RED GUAVA JAM SLICE (PSidium guajava L.)}

\author{
Ika Nur Septiani ${ }^{1)}$, Basito $^{1)}$, Esti Widowati ${ }^{1)}$ \\ 1) Program Studi Ilmu dan Teknologi Pangan, Universitas Sebelas Maret, Surakarta \\ email: septian_ichi@yahoo.com
}

\begin{abstract}
In this research the red guava (Psidium guajava L.) jam slices are made with kind of type (agar and carrageenan) and concentration (1,5\%,2,0\%, and 2,5\%) hydrocolloid in order to figure the influence of that treatments on physical, chemical, and sensory characteristics and to know which treatment resulting the best charactereristic. The analysis was conducted on the evaluation of physical ( $\mathrm{pH}$ and total soluble solid), chemical (water and dietary fiber content), and sensory characteristics. The research had been performed using Factorial Completely Randomized Design (CRD) with one factor, i.e.: combination of type of hydrocolloid with its concentration. Based on the study result, the hydrocolloid with different type had a significant influence on $\mathrm{pH}$, total soluble solid, and total dietary fiber content but not significant on water content and sensory of jam slice. Difference of concentration of hydrocolloid had a significant influence on total dietary fiber content but not significant on $\mathrm{pH}$, total soluble solid, water content and sensory. Increasing addition both of these hydrocolloid caused increasing on $\mathrm{pH}$, water and total dietary fiber content but decreasing on total soluble solid. Agar 1,5\%

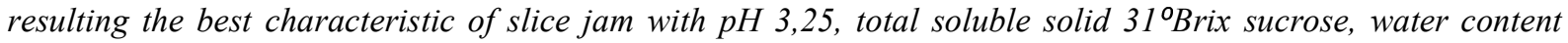
$35,3264 \% \mathrm{wb}$, total dietary fiber content $5,0979 \%$, and had the most favorite in flavor and overall
\end{abstract}

Keywords : agar, carrageenan, guava, jam slice

\section{ABSTRAK}

Selai lembaran jambu biji merah (Psidium guajava L.) dalam penelitian ini dibuat dengan variasi jenis (agar-agar dan karagenan) dan konsentrasi (1,5\%, 2,0\%, dan 2,5\%) hidrokoloid dengan tujuan untuk mengetahui pengaruh konsentrasi agar-agar dan karagenan terhadap karakteristik fisik, kimia, dan sensori serta mengetahui perlakuan yang menghasilkan karakteristik selai lembaran terbaik. Analisis yang dilakukan meliputi evaluasi karakteristik fisik (nilai $\mathrm{pH}$ dan total padatan terlarut), kimia (kadar air dan serat pangan), dan sensori. Metode penelitian menggunakan Rancangan Acak Lengkap satu faktor yaitu kombinasi jenis hirdokoloid dengan konsentrasinya. Berdasarkan hasil penelitian, perbedaan jenis hidrokoloid berpengaruh signifikan terhadap nilai $\mathrm{pH}$, total padatan terlarut, dan kadar serat pangan, serta berpengaruh namun tidak signifikan terhadap kadar air dan sensori. Perbedaan konsentrasi hidrokoloid berpengaruh signifikan terhadap kadar serat pangan serta berpengaruh namun tidak signifikan terhadap $\mathrm{pH}$, total padatan terlarut, kadar air, dan sensori selai lembaran. Penambahan kedua jenis hidrokoloid tersebut menyebabkan peningkatan nilai $\mathrm{pH}$, kadar air, dan kadar serat pangan total namun menurunkan total padatan terlarut. Perlakuan agar-agar konsentrasi 1,5\% menghasilkan selai lembaran terbaik dengan nilai $\mathrm{pH} 3,25$, total padatan terlarut $31^{\circ}$ Brix sukrosa, kadar air 35,3264\% wb, kadar serat pangan total $5,0979 \%$, dan memiliki aroma, rasa, dan overall yang paling disukai.

Kata Kunci : agar-agar, jambu biji, karagenan, selai lembaran

\section{PENDAHULUAN}

Salah satu pangan semi basah berbahan dasar buah yang makin diminati adalah selai buah. Selai yang beredar di pasaran berupa selai oles dengan kemasan menarik namun kurang praktis dalam penyajiannya. Salah satu alternatif supaya selai oles lebih praktis adalah menjadikannya selai lembaran, yaitu modifikasi bentuk selai oles menjadi bentuk lembaran menyerupai keju lembaran dan bersifat lebih padat. Selain itu, pemanfaatan buah menjadi produk selai lembaran dapat meningkatkan nilai ekonomi buah dan umur simpan produk tersebut.

Jambu biji merupakan buah yang berpotensi dibuat selai lembaran karena mengandung serat yang tinggi $(5,60$ $\mathrm{mg} / 100 \mathrm{~g}$ ) (Wirakusumah, 1998) dan pektin (0,5\%) (Hulme, 1974). Produksi jambu biji yang melimpah, pada tahun 2011 di Jawa Tengah sebesar 76,334 ton dan di Jawa Barat 
sebesar 157,030 ton (BPS, 2012) dihadapkan pada masalah pascapanen karena buah ini tergolong klimakterik dan umur simpannya pada suhu ruang relatif singkat, sekitar 2-3 hari (Phebe dan Ong, 2010). Oleh karena itu, diperlukan pengembangan diversifikasi produk olahan jambu biji, salah satunya yaitu sebagai bahan baku selai lembaran.

Pembuatan selai lembaran memerlukan bahan tambahan berupa hidrokoloid sebagai pembentuk tekstur. Jenis hidrokoloid yang dikenal luas dalam industri pangan antara lain agar-agar yang diperoleh dari rumput laut Gracillaria sp dan karagenan yang diperoleh dari Eucheuma sp. Agar-agar diaplikasikan pada bidang pangan sekitar 91\% (Imeson, 2010) dan karagenan sekitar $80 \%$. Peran keduanya dalam industri pangan sebagai pengatur keseimbangan, pengental, dan pembentuk gel (Winarno, 1996) sehingga dapat dimanfaatkan dalam pembentukan tekstur selai lembaran.

Hal yang perlu diperhatikan dalam pembuatan selai lembaran adalah mengenai konsentrasi jenis hidrokoloid, karena apabila konsentrasinya kurang akan menyebabkan tekstur selai terlalu lunak dan tidak bisa dibentuk menjadi lembaran, namun apabila konsentrasinya berlebih akan menyebabkan tekstur selai terlalu kaku. Pada penelitian ini dilakukan pembuatan selai lembaran dari buah jambu biji merah dengan penambahan hidrokoloid berupa agar-agar dan karagenan dengan tujuan untuk mengetahui pengaruh konsentrasi agar-agar dan karagenan terhadap karakteristik fisik, kimia dan sensori, serta menentukan karakteristik selai lembaran terbaik.

\section{METODE PENELITIAN}

\section{Bahan dan Alat}

Bahan yang digunakan untuk membuat selai lembaran antara lain buah jambu biji merah yang dipanen dari Cirebon dan dibeli dari daerah Pasar Nongko Surakarta, agar-agar (Swallow Globe), karagenan yang dibeli dari CV. Tristar Surabaya, gula pasir (Gulaku), margarin (Forvita), asam sitrat, dan air mineral (Aqua). Bahan kimia yang digunakan antara lain aquades, natrium fosfat $\left(\mathrm{NaPO}_{4}\right)$, asam klorida ( $\mathrm{HCl} 4 \mathrm{M}$ ), natrium hidroksida $(\mathrm{NaOH} 4 \mathrm{M}$ ), enzim termamyl, enzim pankreatin, aseton $\left(\mathrm{CH}_{3} \mathrm{COCH}_{3}\right)$, dan etanol $\left(\mathrm{C}_{2} \mathrm{H}_{5} \mathrm{OH}\right)$ 95\%.

Alat-alat yang digunakan untuk membuat selai lembaran adalah blender, wajan antilengket, kompor gas, timbangan, dan sebagainya. Alat-alat untuk analisis antara lain $\mathrm{pH}$ meter (Hanna $\mathrm{pH}$ meter stick PHEP 0-14 pH), hand refraktometer (ATAGO), oven (Memmert UNB 400), alat Sokhlet, neraca analitik OHAUS, desikator, tanur, dan glass ware.

\section{Tahapan Penelitian}

Penelitian ini terdiri dari dua tahap, yaitu penelitian pendahuluan dan penelitian utama. Penelitian pendahuluan dilakukan untuk menentukan formulasi bubur buah dan gula (45\%:55\%, 67\%:33\%, 75\%:25\%) serta penambahan konsentrasi agar-agar dan karagenan $(0,8 \%, 1,0 \%, 1,2 \%, 1,5 \%, 2 \%$, $2,5 \%)$ yang akan digunakan pada penelitian utama. Formulasi terpilih pada penelitian pendahuluan ditunjukkan pada Tabel 1 dan proses pembuatan selai lembaran ditunjukkan Gambar 1.

Tabel 1 Formula Selai Lembaran Jambu Biji Merah

\begin{tabular}{lcc}
\hline \multicolumn{1}{c}{ Bahan } & Proporsi (\%) & Jumlah $(\mathrm{g})$ \\
\hline Bubur buah & 75 & 90 \\
Gula pasir & 25 & 30 \\
Agar-agar/ & 1,$5 ; 2,0 ; 2,5$ & 1,$8 ; 2,4 ; 3$ \\
Karagenan & 5 & 6 \\
Margarin & 0,5 & 0,6 \\
Asam sitrat &
\end{tabular}

\section{Analisis Selai Lembaran}

Analilis karakteristik fisik meliputi derajat keasaman ( $\mathrm{pH})$ menggunakann metode potensiometri (BSN, 1992) dan total padatan terlarut (TPT) menggunakan metode pengukuran indeks bias (AOAC, 1995), karakteristik kimia meliputi kadar air menggunakan metode thermogravimetri (BSN, 2006) dan kadar serat pangan menggunakan metode multi enzimatis (Asp et al., 1983), serta karakteristik sensori menggunakan uji hedonic ranking (Kartika dkk, 1987) meliputi parameter warna, aroma, rasa, tekstur, kelengketan, dan overall. 


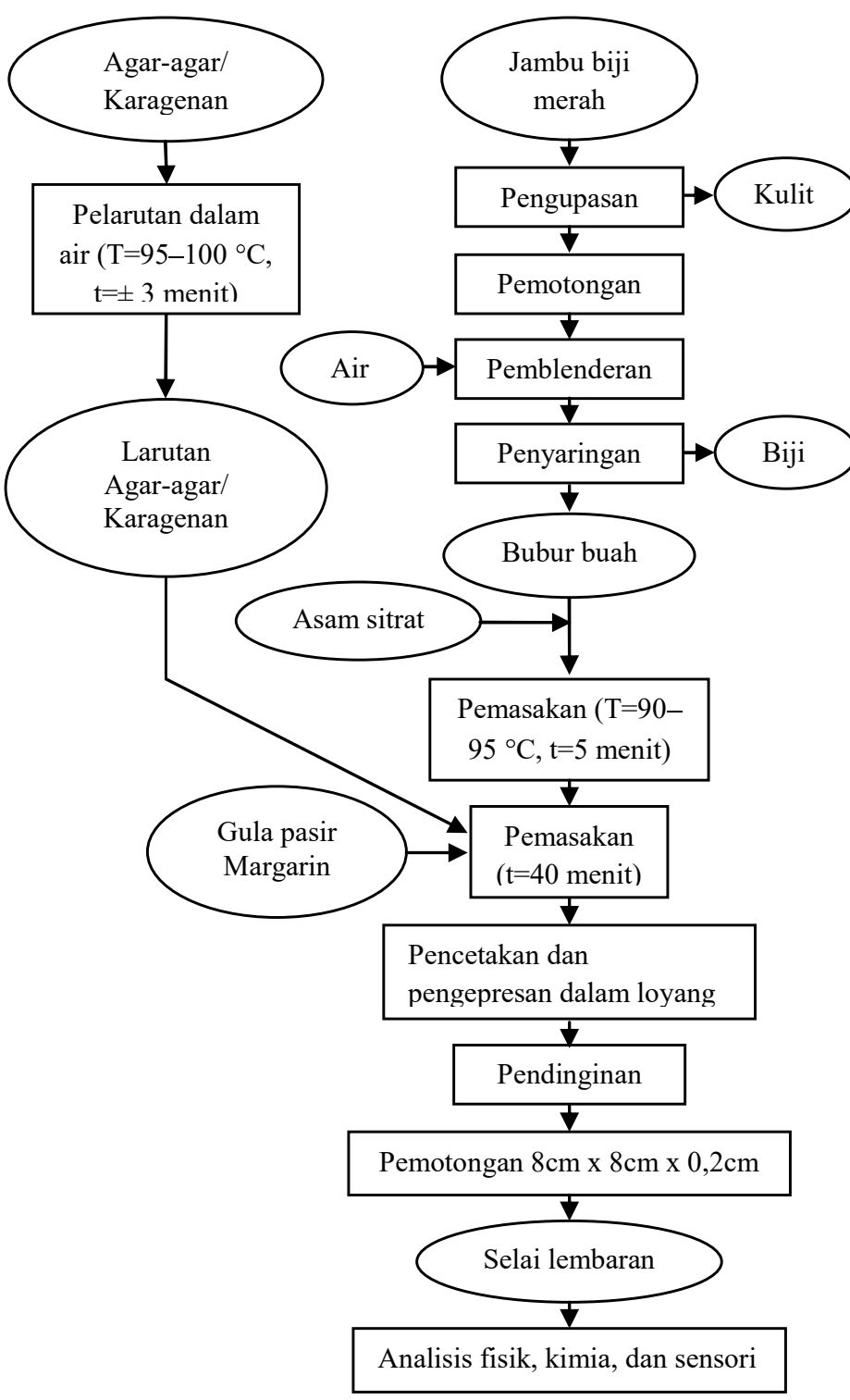

Gambar 1. Diagram Alir Kualitatif Pembuatan Selai Lembaran Jambu Biji Merah

\section{HASIL DAN PEMBAHASAN}

\section{Karakteristik Fisik Selai Lembaran Jambu Biji Merah Derajat Keasaman (pH)}

Derajat keasaman $(\mathrm{pH})$ menunjukkan tingkat keasaman maupun kebasaan suatu produk. Nilai $\mathrm{pH}$ adalah minus logaritma dari konsentrasi ion $\mathrm{H}^{+}$, ditentukan dari molekulmolekul baik yang melepaskan maupun mengikat ion ke dalam larutan (Winarno dan Wiratakusumah, 1974). Berdasarkan Tabel 2, kombinasi perlakuan jenis hidrokoloid yang berbeda pada konsentrasi yang sama berpengaruh signifikan terhadap nilai $\mathrm{pH}$.
Nilai pH kombinasi perlakuan agar-agar lebih rendah (keasaman lebih tinggi) dibandingkan perlakuan karagenan. Hal ini diduga karena agar-agar dan karagenan terdispersi menjadi koloid hidrofilik bermuatan negatif, penambahan asam sitrat yang mengandung ion hidrogen $\left(\mathrm{H}^{+}\right)$akan menetralkan muatan dengan membentuk ikatan hidrogen yang merubah bentuk rantai polimer yang semula lurus menjadi bentuk tiga dimensi untuk menangkap air. Adanya gugus anhidrogalaktosa pada karagenan mengakibatkan daya dispersi berkurang sehingga $\left(\mathrm{H}^{+}\right)$yang terikat dalam selai lembaran berkurang sehingga pengukuran konsentrasi hidrogen rendah (Fachruddin, 1997).

Kombinasi perlakuan jenis hirokoloid yang sama pada konsentrasi yang berbeda berpengaruh namun tidak signifikan terhadap nilai $\mathrm{pH}$ karena jenis dan konsentrasi asam yang digunakan pada setiap perlakuan sama, yaitu asam sitrat dengan konsentrasi 0,5\%

Peningkatan konsentrasi agar-agar maupun karagenan menyebabkan peningkatan nilai $\mathrm{pH}$. Nilai $\mathrm{pH}$ selai lembaran jambu biji merah berkisar 3,25-4,0, sesuai standar berdasarkan U.S. Food and Drug Administration (2007) yaitu nilai $\mathrm{pH}$ selai buah berkisar antara 3,5-4,5.

\section{Total Padatan Terlarut}

Total padatan terlarut (TPT) yang terukur pada penelitan ini adalah gula dalam bentuk sukrosa ( ${ }^{\circ}$ Brix Sukrosa). Berdasarkan Tabel 2, kombinasi perlakuan jenis hidrokoloid yang berbeda pada konsentrasi yang sama berpengaruh signifikan terhadap TPT. TPT kombinasi perlakuan karagenan lebih rendah dibandingkan agar-agar, diduga karena karagenan lebih optimum dalam memerangkap air pada proses pembentukan gel, akibatnya ketersediaan air bebas semakin berkurang sehingga penurunan kelarutan sukrosa lebih banyak sehingga TPTnya lebih sedikit.

Kombinasi perlakuan jenis hidrokoloid yang sama pada konsentrasi yang berbeda berpengaruh namun signifikan terhadap TPT karena penambahan gula pasir (sukrosa) pada setiap perlakuan sama yaitu $25 \%$. Selain itu selisih konsentrasi 
Tabel 2 Karakteristik Fisik Selai Lembaran Jambu Biji Merah

\begin{tabular}{cccc}
\hline Jenis Hidrokoloid & Konsentrasi $(\%)$ & Nilai $\mathrm{pH}$ & TPT $\left({ }^{\circ}\right.$ Brix Sukrosa $)$ \\
\hline Agar-agar & 1,5 & $3,25^{\mathrm{a}}$ & $31^{\mathrm{d}}$ \\
& 2,0 & $3,35^{\mathrm{ab}}$ & $28,5^{\mathrm{cd}}$ \\
Karagenan & 2,5 & $3,50^{\mathrm{abc}}$ & $25^{\mathrm{bc}}$ \\
& 1,5 & $3,60^{\mathrm{bc}}$ & $26^{\mathrm{bc}}$ \\
& 2,0 & $3,75^{\mathrm{cd}}$ & $24^{\mathrm{b}}$ \\
& 2,5 & $4,00^{\mathrm{d}}$ & $19^{\mathrm{a}}$ \\
\hline
\end{tabular}

Keterangan:

*Angka merupakan rata-rata \pm standar deviasi

* Huruf notasi yang berbeda menunjukkan beda nyata pada taraf signifikansi $(\alpha) 5 \%$

hidrokoloid $0,5 \%$ ikatannya terhadap air masih lemah.

Peningkatan konsentrasi agar-agar maupun karagenan menyebabkan penurunan TPT, diduga karena agar-agar atau karagenan mengikat air bebas untuk membentuk gel bersaing dengan sukrosa sehingga jumlah sukrosa yang larut berkurang dan menurunkan jumlah sukrosa yang terukur sebagai padatan terlarut. Nilai TPT perlakuan agar-agar 25-31 ${ }^{\circ}$ Brix dan karagenan 19-26 ${ }^{0}$ Brix, belum sesuai dengan standar TPT selai berdasarkan SNI 01-3746-1995, yaitu minimal $65 \%$ b/b atau $65^{\circ}$ Brix (BSN, 1995). Hal ini disebabkan karena konsentrasi gula pasir yang ditambahkan lebih rendah yaitu $25 \%$ dan agar-agar maupun karagenan akan mengikat air bebas sehingga kelarutan sukrosa berkurang. Selain itu, selama pemasakan sukrosa mengalami hidrolisis menjadi gula invert berupa glukosa dan fruktosa.

\section{Karakteristik Kimia Selai Lembaran Jambu Biji Merah}

\section{Kadar Air (\% wb)}

Kadar air sangat penting dalam menentukan daya awet dari bahan makanan karena mempengaruhi sifat fisik, perubahanperubahan kimia, perubahan mikrobiologi dan perubahan enzimatis (Buckle dkk., 1987). Berdasarkan Tabel 3, kombinasi perlakuan jenis hidrokoloid yang berbeda pada konsentrasi yang sama berpengaruh signifikan terhadap kadar air. Kadar air kombinasi perlakuan agar-agar lebih rendah dibandingkan perlakuan karagenan, diduga karena karagenan lebih optimum dalam memerangkap air pada proses pembentukan gel sehingga pada saat pengukuran kadar air menunjukkan bahwa perlakuan karagenan memiliki kadar air yang lebih tinggi daripada perlakuan agar-agar. Kandungan sulfat yang tinggi pada karagenan yaitu $20-50 \%$ (Winarno, 1996) mempengaruhi tingkat viskositasnya, mudah terdegradasi pada $\mathrm{pH}$ asam, dan bersifat sineresis. Fenomena sineresis dialami oleh sampel selai lembaran dengan hidrokoloid berupa karagenan selama disimpan dalam suhu refri.

Kombinasi perlakuan jenis hirokoloid yang sama pada konsentrasi yang berbeda berpengaruh namun signifikan terhadap kadar air karena penambahan air selama proses pengolahan selai lembaran pada setiap perlakuan seragam.

Peningkatan konsentrasi agar-agar maupun karagenan menyebabkan peningkatan kadar air karena dalam proses pembentukan gel air yang dapat terikat oleh hidrokoloid semakin banyak. Kisaran kadar air selai lembaran jambu biji merah 35,3264$46,9457 \% \mathrm{wb}$, sesuai standar kadar air pangan semibasah yaitu 30-50\% (Buckle dkk., 1987).

\section{Kadar Serat Pangan (\%)}

Serat pangan adalah bagian dari bahan pangan yang tidak dapat dihidrolisis oleh enzim-enzim pencernaan (Muchtadi, 2000), terdiri dari serat pangan larut (Soluble Dietary Fiber/SDF) dan serat pangan tidak larut (Insoluble Dietary Fiber/IDF). SDF adalah serat pangan yang dapat larut dalam air hangat atau panas, terdiri dari pektin, musilase, dan gum. IDF adalah serat pangan yang tidak larut dalam air panas atau dingin, komponen IDF yang berupa karbohidrat adalah lignin sedangkan non karbohidrat 
Tabel 3 Karakteristik Kimia Selai Lembaran Jambu Biji Merah

\begin{tabular}{cccccc}
\hline $\begin{array}{c}\text { Jenis } \\
\text { Hidrokoloid }\end{array}$ & $\begin{array}{c}\text { Konsentrasi } \\
(\%)\end{array}$ & $\begin{array}{c}\text { Kadar Air } \\
(\% \mathrm{wb})\end{array}$ & $\begin{array}{c}\text { Serat Pangan } \\
\text { Tidak Larut }(\%)\end{array}$ & $\begin{array}{c}\text { Serat Pangan } \\
\text { Larut }(\%)\end{array}$ & $\begin{array}{c}\text { Serat Pangan } \\
\text { Total }(\%)\end{array}$ \\
\hline Agar-agar & 1,5 & $35,3264^{\mathrm{a}}$ & $1,4046^{\mathrm{a}}$ & $3,6933^{\mathrm{d}}$ & $5,0979^{\mathrm{c}}$ \\
& 2,0 & $39,4142^{\mathrm{ab}}$ & $1,8180^{\mathrm{a}}$ & $4,2653^{\mathrm{e}}$ & $6,0833^{\mathrm{d}}$ \\
& 2,5 & $43,5527^{\mathrm{b}}$ & $2,0804^{\mathrm{c}}$ & $4,8982^{\mathrm{f}}$ & $6,9785^{\mathrm{e}}$ \\
Karagenan & 1,5 & $44,1652^{\mathrm{b}}$ & $1,2773^{\mathrm{a}}$ & $2,1960^{\mathrm{a}}$ & $3,4734^{\mathrm{a}}$ \\
& 2,0 & $45,0332^{\mathrm{b}}$ & $1,3822^{\mathrm{a}}$ & $2,6138^{\mathrm{b}}$ & $3,9960^{\mathrm{b}}$ \\
& 2,5 & $46,9457^{\mathrm{b}}$ & $1,2396^{\mathrm{a}}$ & $2,9506^{\mathrm{c}}$ & $4,1902^{\mathrm{b}}$ \\
\hline
\end{tabular}

Keterangan:

*Angka merupakan rata-rata \pm standar deviasi

* Huruf notasi yang berbeda menunjukkan beda nyata pada taraf signifikansi $(\alpha) 5 \%$

adalah selulosa dan hemiselulosa (Winarno, 2008). Berdasarkan Tabel 3, kombinasi perlakuan jenis hidrokoloid yang berbeda pada konsentrasi yang sama secara umum berpengaruh signifikan terhadap kadar serat pangan tidak larut. Kombinasi perlakuan agar-agar dengan konsentrasi yang berbeda berpengaruh signifikan terhadap kadar serat pangan tidak larut sedangkan kombinasi perlakuan karagenan dengan konsentrasi yang berbeda berpengaruh namun tidak signifikan. Serat pangan tidak larut sebagian besar berasal dari dinding sel jambu biji merah, yang secara kimia terdiri dari beberapa jenis serat tidak larut yang berupa karbohidrat yaitu lignin sedangkan non karbohidrat yaitu selulosa dan hemiselulosa (Winarno, 2008).

Kombinasi perlakuan jenis dan konsentrasi hidrokoloid yang berbeda berpengaruh signifikan terhadap kadar serat pangan larut. Serat pangan larut berasal dari polisakarida pada agar-agar dan karagenan dan dari pektin dari jambu biji merah. Kadar serat pangan larut perlakuan agar-agar lebih tinggi dibandingkan karagenan karena karagenan memiliki gugus anhidrogalaktosa yang bersifat hidrofobik sehingga kelarutannya dalam air berkurang (Towle, 1973).

Kombinasi perlakuan jenis dan konsentrasi hidrokoloid yang berbeda secara umum berpengaruh signifikan terhadap kadar serat pangan total yang merupakan hasil penjumlahan dari kadar serat pangan tidak larut dengan serat pangan larut. Kadar serat pangan total perlakuan agar-agar berkisar antara 5,0979-6,9785\% dan perlakuan karagenan berkisar antara 3,4734-4,1902\%.
Peningkatan konsentrasi agar-agar maupun karagenan menyebabkan peningkatan kadar serat pangan total. Faktor spesies, tingkat kematangan, bagian tanaman yang dikonsumsi, dan perlakuan terhadap bahan tersebut sangat berpengaruh terhadap komposisi kimia dan fisik dari serat pangan serta peran fisiologis serat dalam tubuh (Muchtadi 2000).

\section{Karakteristik Sensori Selai Lembaran Jambu Biji Merah}

\section{Warna}

Zat yang berperan memberikan warna merah pada selai lembaran adalah likopen dari jambu biji merah (Parimin, 2007) dan warna karamel dari pemanasan gula (sukrosa). Berdasarkan Tabel 4, tingkat kesukaan panelis tertinggi adalah kombinasi perlakuan karagenan $1,5 \%$ karena menghasilkan warna selai lembaran yang merah cerah. Tingkat kesukaan terendah adalah kombinasi perlakuan karagenan 2,5\% karena karagenan banyak mengimobilisasi air sehingga menyebabkan warna selai menjadi merah agak pucat. Konsentrasi karagenan yang tinggi cenderung dihasilkan gel yang kokoh. Efek gelasi yang tinggi diperkirakan dapat menutupi warna (Harijono, 2001) selai lembaran jambu biji merah. Oleh karena itu, nilai warna cenderung semakin kecil pada konsentrasi karagenan yang lebih besar. Secara umum, perbedaan jenis dan konsentrasi hidrokoloid berpengaruh namun signifikan terhadap warna selai lembaran jambu biji merah. 
Tabel 4 Karakteristik Sensori Selai Lembaran Jambu Biji Merah

\begin{tabular}{cccccccc}
\hline Jenis & Konsentrasi & \multicolumn{7}{c}{ Parameter Sensori } \\
\cline { 3 - 7 } Hidrokoloid & $(\%)$ & Warna & Aroma & Tekstur & Kelengketan & Rasa & Overall \\
\hline Agar-agar & 1,5 & $-0,09^{\mathrm{a}}$ & $0,37^{\mathrm{b}}$ & $-0,13^{\mathrm{ab}}$ & $0,11^{\mathrm{a}}$ & $0,19^{\mathrm{b}}$ & $0,22 \mathrm{~b}$ \\
& 2,0 & $0,05^{\mathrm{ab}}$ & $-0,21^{\mathrm{a}}$ & $-0,04^{\mathrm{ab}}$ & $-0,08^{\mathrm{a}}$ & $-0,01^{\mathrm{ab}}$ & $-0,21^{\mathrm{a}}$ \\
& 2,5 & $0,06^{\mathrm{ab}}$ & $-0,16^{\mathrm{a}}$ & $-0,26^{\mathrm{a}}$ & $-0,12^{\mathrm{a}}$ & $-0,09^{\mathrm{ab}}$ & $-0,07^{\mathrm{ab}}$ \\
Karagenan & 1,5 & $0,33^{\mathrm{b}}$ & $0,16^{\mathrm{ab}}$ & $0,25^{\mathrm{b}}$ & $0,11^{\mathrm{a}}$ & $0,05^{\mathrm{ab}}$ & $0,15^{\mathrm{ab}}$ \\
& 2,0 & $-0,17^{\mathrm{a}}$ & $-0,17^{\mathrm{a}}$ & $0,13^{\mathrm{ab}}$ & $-0,08^{\mathrm{a}}$ & $0,08^{\mathrm{ab}}$ & $0,10^{\mathrm{ab}}$ \\
& 2,5 & $-0,19^{\mathrm{a}}$ & $0,02^{\mathrm{ab}}$ & $0,09^{\mathrm{ab}}$ & $0,06^{\mathrm{a}}$ & $-0,24^{\mathrm{a}}$ & $-0,19^{\mathrm{a}}$ \\
\hline
\end{tabular}

Keterangan:

* Huruf notasi yang berbeda menunjukkan beda nyata pada taraf signifikansi $(\alpha) 5 \%$

* Semakin tinggi nilai (positif) maka semakin disukai, semakin rendah nilai (negatif)semakin tidak disukai

\section{Aroma}

Aroma selai lembaran dihasilkan dari perpaduan aroma khas dari jambu biji, gula, dan asam yang ditambahkan. Berdasarkan Tabel 4, tingkat kesukaan panelis tertinggi terhadap parameter aroma adalah kombinasi perlakuan agar-agar 1,5\% karena konsentrasi hidrokoloid paling sedikit sehingga tidak terlalu menutupi aroma khas buah jambu biji merah. Buah yang matang penuh akan memberikan aroma yang lebih kuat daripada yang hampir matang sehingga menghasilkan aroma selai yang memiliki aroma khas jambu biji. Selain itu, aroma pada selai lembaran juga berasal dari gula yang dipanaskan sehingga membentuk aroma karamel (Winarno, 1997). Tingkat kesukaan panelis terendah adalah kombinasi perlakuan agaragar 2,0\%, namun secara umum, kombinasi perlakuan perbedaan jenis dan konsentrasi hidrokoloid berpengaruh namun signifikan terhadap aroma selai lembaran jambu biji merah.

\section{Tekstur}

Tekstur selai lembaran terkait dengan sifat pembentukan gel hidrokoloid yang ditambahkan. Berdasarkan Tabel 4, tingkat kesukaan panelis tertinggi terhadap parameter tekstur adalah kombinasi perlakuan karagenan $1,5 \%$ dan terendah adalah kombinasi perlakuan agar-agar 2,5\%. Secara umum kombinasi perlakuan perbedaan jenis dan konsentrasi hidrokoloid berpengaruh namun signifikan terhadap tekstur selai lembaran jambu biji merah. Gel yang terbentuk dari kappa karagenan mempunyai tekstur yang rigid atau mudah pecah (Fardiaz, 1989). Tekstur yang sangat kenyal akan menurunkan penerimaan kegoman suatu bahan pangan (energi yang diperlukan untuk menghancurkan makanan semibasah sehingga kondisinya siap ditelan). Sifat kegoman atau kunyah dari selai lembaran jambu biji merah menjadi penting disebabkan selai ini akan dikonsumsi bersama roti sehingga tingkat kunyah dari selai tersebut paling tidak sama dengan selai oles atau keju lembaran yang cenderung bersifat basah dan mudah dikunyah.

\section{Kelengketan}

Kelengketan menunjukkan daya lekat selai lembaran terhadap roti. Selai lembaran sebaiknya tidak lengket pada roti. Berdasarkan Tabel 4, tingkat kesukaan panelis tertinggi terhadap parameter kelengketan adalah kombinasi perlakuan karagenan $1,5 \%$ dan terendah adalah kombinasi perlakuan agar-agar 2,5\%. Kelengketan selai lembaran dipengaruhi oleh adanya penambahan margarin supaya selai tidak lengket. Perlakuan perbedaan jenis dan konsentrasi hidrokoloid berpengaruh namun signifikan karena penambahan konsentrasi margarin pada masing-masing perlakuan sama, yaitu 5\%. Selai lembaran jambu biji merah memiliki kelengketan cukup baik karena pada saat diletakkan di atas permukaan roti, selai tidak melekat dan lengket pada roti.

\section{Rasa}

Faktor yang mempengaruhi rasa diantaranya adalah senyawa kimia, suhu, konsentrasi dan interaksi dengan komponen rasa lain (Winarno, 2008). Berdasarkan Tabel 4, tingkat kesukaan panelis tertinggi terhadap parameter rasa adalah kombinasi 
Tabel 5 Matriks Pemilihan Selai Lembaran Jambi Biji Merah Berdasarkan Karakteristik Fisik, Kimia dan Sensori

\begin{tabular}{|c|c|c|c|c|c|c|}
\hline \multirow{3}{*}{ Parameter } & \multicolumn{6}{|c|}{ Selai Lembaran Jambu Biji Merah } \\
\hline & \multicolumn{3}{|c|}{ Konsentrasi Agar-agar (\%) } & \multicolumn{3}{|c|}{ Konsentrasi Karagenan (\%) } \\
\hline & 1,5 & 2,0 & 2,5 & 1,5 & 2,0 & 2,5 \\
\hline Nilai $\mathrm{pH}$ & $3,25^{\mathrm{a}}$ & $3,35^{\mathrm{ab}}$ & $3,50^{\mathrm{abc}}$ & $3,60^{\mathrm{bc}}$ & $3,75^{\mathrm{cd}}$ & $4,00^{\mathrm{d}}$ \\
\hline Nilai TPT & $31,0^{\mathrm{d}}$ & $28,5^{\mathrm{cd}}$ & $25,0^{\mathrm{bc}}$ & $26,0^{\mathrm{bc}}$ & $24,0^{\mathrm{b}}$ & $19,0^{\mathrm{a}}$ \\
\hline Kadar Air & $35,3264^{\mathrm{a}}$ & $39,4142^{a b}$ & $43,5527^{\mathrm{b}}$ & $44,1652^{b}$ & $45,0332^{\mathrm{b}}$ & $46,9457^{\mathrm{b}}$ \\
\hline Kadar Serat Pangan & $5,0979^{c}$ & $6,0833^{\mathrm{d}}$ & $6,9785^{\mathrm{e}}$ & $3,4734^{\mathrm{a}}$ & $3,9960^{\mathrm{b}}$ & $4,1902^{b}$ \\
\hline Warna* & $-0,09^{a}$ & $0,05^{\mathrm{ab}}$ & $0,06^{\mathrm{ab}}$ & $0,33^{\mathrm{b}}$ & $-0,17^{\mathrm{a}}$ & $-0,19^{a}$ \\
\hline Aroma* & $0,37^{\mathrm{b}}$ & $-0,21^{\mathrm{a}}$ & $-0,16^{\mathrm{a}}$ & $0,16^{\mathrm{ab}}$ & $-0,17^{\mathrm{a}}$ & $0,02^{\mathrm{ab}}$ \\
\hline Tekstur* & $-0,13^{\mathrm{ab}}$ & $-0,04^{\mathrm{ab}}$ & $-0,26^{\mathrm{a}}$ & $0,25^{b}$ & $0,13^{\mathrm{ab}}$ & $0,09^{\mathrm{ab}}$ \\
\hline Kelengketan* & $0,11^{\mathrm{a}}$ & $-0,08^{\mathrm{a}}$ & $-0,12^{\mathrm{a}}$ & $0,11^{\mathrm{a}}$ & $-0,08^{\mathrm{a}}$ & $0,06^{\mathrm{a}}$ \\
\hline Rasa* & $0,19^{b}$ & $-0,01^{\mathrm{ab}}$ & $-0,09^{\mathrm{ab}}$ & $0,05^{\mathrm{ab}}$ & $0,08^{\mathrm{ab}}$ & $-0,24^{\mathrm{a}}$ \\
\hline Overall* & $0,22^{b}$ & $-0,21^{\mathrm{a}}$ & $-0,07^{\mathrm{ab}}$ & $0,15^{\mathrm{ab}}$ & $0,10^{\mathrm{ab}}$ & $-0,19^{a}$ \\
\hline
\end{tabular}

Keterangan:

Huruf notasi yang berbeda menunjukkan beda nyata pada taraf signifikansi $(\alpha) 5 \%$

*) Semakin tinggi nilai (positif) maka semakin disukai, semakin rendah nilai (negatif) semakin tidak disukai

perlakuan agar-agar $1,5 \%$ dan terendah adalah kombinasi perlakuan karagenan 2,5\%. Secara umum, perlakuan perbedaan jenis dan konsentrasi hidrokoloid berpengaruh namun tidak signifikan terhadap rasa karena agaragar dan karagenan tidak memiliki rasa yang khas atau memiliki rasa netral. Agar-agar yang baik adalah yang tidak memiliki rasa yang mencolok atau tidak berasa sama sekali (Winarno 1996), begitu pula karagenan. Hal ini untuk menghindari terpengaruhnya rasa suatu produk oleh agar-agar maupun karagenan, yang biasanya hanya merupakan food additives dan diberikan dalam jumlah yang terbatas.

\section{Overall}

Penerimaan secara overall (keseluruhan) menunjukkan penilaian panelis secara umum terhadap suatu produk, bukan merupakan faktor mutlak untuk menentukan produk pangan yang terpilih. Hal ini mencakup hasil penilaian panelis secara umum terhadap parameter warna, aroma, tekstur, kelengketan, dan rasa selai lembaran jambu biji merah. Berdasarkan Tabel 4, tingkat kesukaan panelis tertinggi terhadap parameter overall adalah kombinasi perlakuan agar-agar $1,5 \%$ dan terendah adalah kombinasi perlakuan karagenan 2,5\%. Secara umum, perlakuan perbedaan jenis dan konsentrasi hidrokoloid tidak berpengaruh sinifikan terhadap overall karena penilaian terhadap parameter warna, aroma, kelengketan, tekstur, dan rasa secara umum berpengaruh namun tidak signifikan.

\section{Penentuan Karakteristik Selai Lembaran Jambu Biji Merah Terpilih}

Hasil penelitian menunjukkan karakteristik fisik, kimia dan sensori dari keenam sampel selai lembaran jambu biji merah dengan perlakuan penambahan agaragar dan karagenan. Berdasarkan hasil tersebut dipilih salah satu selai lembaran jambu biji merah dengan karakteristik fisik, kimia dan sensori yang disukai.

Tabel 5 menunjukkan bahwa selai lembaran jambu biji merah terpilih berdasarkan karakteristik fisik, kimia, dan sensori adalah selai lembaran jambu biji merah kombinasi perlakuan agar-agar 1,5\%. Sampel tersebut memiliki nilai $\mathrm{pH}$ terendah yaitu 3,25, nilai TPT tertinggi sebesar 31,0 ${ }^{\circ}$ Brix sukrosa, kadar air terendah sebesar 35,3264\%wb, meskipun memiliki kadar total serat pangan lebih rendah, yaitu 5,0979\%. Berdasarkan analisis sensori, sampel tersebut paling disukai oleh panelis berdasarkan parameter aroma, rasa, dan overall. Berdasarkan semua parameter analisis diketahui bahwa nilai pada selai lembaran jambu biji merah kombinasi perlakuan agaragar 1,5\% memenuhi 6 dari 10 parameter analisis, nilai pada selai lembaran jambu biji 
merah kombinasi perlakuan agar-agar 2,5\% memenuhi 1 dari 10 parameter analisis dengan kadar serat pangan tertinggi sebesar $6,9785 \%$. Selai lembaran jambu biji merah kombinasi perlakuan karagenan 1,5\% memenuhi 3 dari 10 parameter analisis berdasarkan warna, tekstur, dan kelengketan. Selai lembaran jambu biji merah kombinasi perlakuan agar-agar 2,0\%, karagenan 2,0\% dan 2,5\% tidak memenuhi salah satu dari 10 parameter analisis.

\section{KESIMPULAN DAN SARAN}

\section{Kesimpulan}

1. Perbedaan jenis hidrokoloid (agar-agar dan karagenan) pada konsentrasi yang sama berpengaruh signifikan terhadap $\mathrm{pH}$, total padatan terlarut (TPT), dan kadar serat pangan total, serta berpengaruh namun tidak signifikan terhadap kadar air dan sensori, sementara perbedaan konsentrasi hidrokoloid $(1,5 \%, 2,0 \%$, dan $2,5 \%$ ) berpengaruh signifikan terhadap kadar serat pangan serta berpengaruh namun tidak signifikan terhadap $\mathrm{pH}$, TPT, kadar air, dan sensori selai lembaran jambu biji merah. Peningkatan konsentrasi kedua jenis hidrokoloid tersebut menyebabkan peningkatan $\mathrm{pH}$, kadar air, dan kadar serat pangan total namun menurunkan TPT.

2. Selai lembaran jambu biji merah terpilih adalah kombinasi perlakuan agar-agar $1,5 \%$ yang memiliki karakteristik nilai $\mathrm{pH}$ $(3,25)$, TPT (31 ${ }^{\circ}$ Brix sukrosa), kadar air $(35,3264 \% \mathrm{wb})$, dan kadar serat pangan total $(5,0979 \%)$, serta memiliki aroma, rasa, dan overall yang paling disukai oleh konsumen.

\section{Saran}

Penelitian mengenai selai lembaran jambu biji merah merupakan penelitian tahap awal sehingga dibutuhkan penelitian lanjutan terhadap produk ini mengenai masalah sineresis yang terjadi pada selai lembaran terutama yang menggunakan hidrokoloid berupa karagenan. Sineresis dapat dikurangi dengan menambahkan konjak glukomannan atau menambahkan ion $\mathrm{K}^{+}$dalam bentuk garam kalium klorida $(\mathrm{KCl})$ dengan konsentrasi tertentu.

\section{DAFTAR PUSTAKA}

AOAC, 1995. Method of Analysis. Association of Official Analytical Chemistry International, Gaithersburg.

Asp, N.G., Johansson, Halmer, and Siljestrom. 1983. Rapid Enzymatic Assay of Insoluble and Soluble Dietary Fiber. J. Agr. Food Chem. 31: 476-482.

Badan Pusat Statistik Republik Indonesia, 2012. Produksi Buah-buahan di Indonesia. Badan Pusat Statistik Republik Indonesia.

Badan Standardisasi Nasional, 1992. Cara Uji Makanan dan Minuman. SNI 012891-1992. Badan Standardisasi Nasional, Jakarta.

1995. Selai Buah. SNI 01-3746-1995. Badan Standardisasi Nasional, Jakarta. , 2006. Cara Uji

Kimia-Bagian 2: Penentuan Kadar Air pada Produk Perikanan. SNI 01-2354.22006. Badan Standarisasi Nasional, Jakarta.

Buckle, K. A., R. A. Edwards, G. H. Fleet, and Wooton. 1987. Ilmu Pangan. Penerjemah H. Purnomo dan Adiono. UI Press, Jakarta.

Fardiaz, D., 1989. Hidrokoloid. Laboratorium Kimia dan Biokimia Pangan. Pusat Antar Universitas Pangan dan Gizi, Institut Pertanian Bogor, Bogor.

Food and Drug Administration. Approximate pH and Foods and Food Product. Center of Food Safety and Applied And Nutrition, USA.

Glicksman, M., 1983. Food Hydrocolloids Volume II. COC Press Inc., Boca Raton. Florida.

Harijono, J. Kusnadi, dan S. A. Mustikasari, 2001. Pengaruh Kadar Karaginan dan Total Padatan Terlarut Sari Buah Apel Muda terhadap Aspek Kualitas Permen Jelly. Jurnal Teknologi Pertanian, Vol. 2, No. 2, Agustus 2001: 110-116. 
Hulme, A.C., 1974. Food Science and Technology Volume I (A Series of Monographs): Biochemistry of Fruit and Their Products. Academic Press, New York and London.

Imeson, 2010. Food Stabilisers, Thickeners and Gelling Agents. Blackwell Publishing Ltd., United Kingdom.

Kartika, B., P. Hastuti, dan W. Suprapto, 1987. Pedoman Uji Indrawi Bahan Pangan. Pusat Universitas Pangan dan Gizi. UGM Press, Yogyakarta.

Muchtadi D. 2000. Sayur-sayuran, Sumber Serat dan Antioksidan : Mencegah Penyakit Degeneratif. Bogor : Jurusan Teknologi Pangan dan Gizi, Fateta, Institut Pertanian Bogor.

Parimin, 2007. Jambu Biji: Budi Daya dan Ragam Pemanfaatannya. Penebar Swadaya, Jakarta.

Phebe D. and P.T. Ong, 2010. Extending 'Kampuchea' Guava Shelf-Life at $27^{\circ} \mathrm{C}$ Using1-Methylcyclopropene. International Food Research Journal 17:63-69.

Towle, G.A. 1973. Carrageenan. dalam Whistler R.L (edt).Industrial Gums. Academic Press, New York.

Winarno F.G., 1996. Teknologi Pengolahan Rumput Laut. Pustaka Sinar Harapan, Jakarta.

, 1997. Kimia Pangan dan Gizi. Gramedia Pustaka Utama, Jakarta.

Gizi. M-Brio Press, Bogor.

Winarno, F. G. dan M. A. Wirakartakusumah, 1974. Fisiologi Lepas Panen. Departemen Teknologi Hasil Pertanian. Fatemeta. IPB, Bogor.

Wirakusumah, E.S., 1998. Buah dan Sayur untuk Terapi. Penebar Swadaya, Jakarta. 